\title{
Cellulolytic enzymes of the obligately biotrophic rust fungus Uromyces viciae-fabae are regulated differentiation-specifically
}

\author{
S. HEILER, K. MENDGEN AND H. DEISING* \\ Universität Konstanz, Fakultät für Biologie, Phytopathologie, Universitätsstr. 10, W-7750 Konstanz, Germany
}

Uredospores of the obligately biotrophic broad bean rust fungus Uromyces viciae-fabae form infection structures on artificial membranes providing a thigmotropic signal. In nature these are essential for invasion of the host plant through the stomata. This experimental system was used to analyse the production of cellulolytic enzymes during the differentiation of rust infection structures.

Low cellulase activity was detected in dormant spores and in germ tubes. Enzyme activity increased during appressorium development and reached a maximum when infection hyphae and haustorial mother cells were formed. Seven cellulolytic enzymes were separated by chromatofocusing on DEAE $=$ Si500 and PBE 94 exchangers. At least two cellulases, characterized by isoelectric points of $7 \cdot 1$ and $7 \cdot 3$, were identified as endo-cellulases. The neutral enzyme forms increased from $3.3 \%$ of the total activity at appressorium formation to $36.6 \%$ when infection hyphae were formed ( $18 \mathrm{~h}$ p.i.), and to $45.4 \%$ in haustorial mother cells ( $24 \mathrm{~h}$ p.i.). Cellulase activity of the rust fungus is neither substrate-inducible nor catabolite repressible. The regulation of these enzymes appears to be strictly controlled by the differentiation of infection structures, and is therefore distinct from cellulases of necrotrophs and saprophytes investigated thus far.

Plant cell walls represent barriers between a host plant and an attacking pathogen. Therefore, cell wall-degrading enzymes of plant pathogenic fungi are thought to play important roles during infection (Wood, 1960; Cooper, 1984). In some interactions between plants and fungal pathogens, enzymes capable of breaching the plant's physical defence barriers are thought to be virulence or even pathogenicity factors (Köller, Allan \& Kolattukudy, 1982; Crawford \& Kolattukudy, 1987; Dickmann, Podila \& Kolattukudy, 1989). Plant cell wall polymer-degrading enzymes of several necrotrophic fungi have, in general, been found to be regulated by substrate induction and catabolite repression (Crawford \& Kolattukudy, 1987; Urbanek, 1989).

In contrast, the mechanism of cell wall penetration by obligately biotrophic fungi is barely understood. In an early publication, Van Sumere, Van Sumere-De Preter \& Ledingham (1957) showed that uredospores of the wheat stem rust fungus Puccinia graminis f.sp. tritici contain cellulases and hemicellulases. In germ tubes growing on pectin agar, substrateinducible polygalacturonase activity was found. On the other hand, Cooper (1984) reported that cellulase activity was not detectable in a number of obligate biotrophs, i.e., in uredospores of the broad bean rust and the French bean rust fungus ( $U$. viciae-fabae and $U$. appendiculatus), in conidia of the powdery mildew fungus Erysiphe graminis, and in sporangia of

\footnotetext{
- Corresponding author.

Abbreviations: CMC, carboxymethyl cellulose; hp.i., hours postinoculation; kat, katal (mole s${ }^{-1}$ ); PMSF, phenylmethylsulfonyl fluoride.
}

the downy mildew fungus Bremia lactucae. These investigations of wall-degrading enzymes of rust fungi (Van Sumere et al., 1957: Cooper, 1984), do not take into account that cellulases could be formed and/or secreted at distinct stages of differentiation of infection structures by the rust fungus, i.e., when they are needed to penetrate the host cell wall. In a more recent review, Keon, Byrde \& Cooper (1987) report on cellulase activity in $E$. graminis that had differentiated appressoria, and thus support the idea of differentiationspecificity of cell wall-degrading enzymes in obligate biotrophs.

Uredosporelings of most rust fungi differentiate a complex series of infection structures in order to invade the host leaf through the stomata (Mendgen et al., 1988). Upon perception of the topographic stimulus provided by the stomatal guard cells (Hoch et al., 1987), germ tube growth ceases and an appressorium is formed. Subsequently, the penetration peg develops, and in the substomatal chamber of the leaf the substomatal vesicle develops, which, in turn, elongates to give rise to the infection hypha. At the tip of the latter structure, the haustorial mother cell is formed upon contact with a plant mesophyll cell. Electron microscopical studies have shown that the infection peg developed by the haustorial mother cell is surrounded by a highly localized zone of disintegrated plant cell wall material (Chong, Harder \& Rohringer, 1981; Taylor \& Mims, 1991), suggesting the involvement of cell walldegrading enzymes.

Since the early work of Dickinson (1949), using collodion membranes with oil inclusions to mimic the surface 
topography of plant leaves, several membranes of different materials have been used to induce the differentiation of infection structures of rust fungi in the absence of the host plant (Wynn, 1976; Staples et al., 1983; Hoch et al., 1987). Deising, jungblut \& Mendgen (1991), using scratched polyethylene membranes, demonstrated that thigmo-induction of uredosporelings resulted in highly synchronized formation of typical infection structures of the broad bean rust fungus Uromyces viciae-fabae. This system enabled investigation of the formation of enzymes potentially involved in penetration of the host cell wall and their regulation during differentiation of infection structures in the absence of the host plant.

Here we use this system and show for the first time that the broad bean rust fungus $U$. viciae-fabae produces cellulosedegrading enzymes, and that these destructive enzymes are not controlled by substrate induction and catabolite repression, but are differentiation-specific. Furthermore, the substrate specificity and the extracellular/intracellular distribution of the enzymes were studied and the different enzymes were partially characterized.

\section{MATERIALS AND METHODS}

\section{Organism}

Uredospores of $U$. viciae-fabae (Pers.) Schroet., isolate 12, were used throughout this study. The uredinial culture was kept as described by Deising et al. (1991). Microscopical examination ensured that the uredospores produced under these conditions were not contaminated with spores of other fungi.

\section{Differentiation of infection structures}

Approximately $180 \mathrm{mg}$ uredospores were dusted onto a scratched polyethylene membrane $\left(1870 \mathrm{~cm}^{2}\right)$. Each membrane was sprayed with $4 \mathrm{ml}$ sterile distilled $\mathrm{H}_{2} \mathrm{O}$ and incubated in the dark at $19^{\circ} \mathrm{C}$ at $100 \%$ relative humidity for different periods of time. When the effect of differentiation of infection structures on enzyme formation was analyzed, thigmoinducing polyethylene membranes and glass plates providing no thigmotropic signal (control) were used. In these experiments, uredospores that had been washed in sterile distilled water for $30 \mathrm{~min}$ were dried and dusted onto glass plates and polyethylene membranes.

To exclude the possibility that bacterial contaminants contribute to the cellulase activity, membranes were sprayed with $4 \mathrm{ml}$ of either cycloheximide $\left(0.1,0.5\right.$ or $\left.1.0 \mu \mathrm{g} \mathrm{ml}^{-1}\right)$, ampicillin $\left(100 \mu \mathrm{g} \mathrm{m}^{-1}\right)$, or streptomycin sulphate $(100 \mu \mathrm{g}$ $\mathrm{ml}^{-1}$ ). All inhibitors were from Sigma, Deisenhofen, Germany.

Membranes were sprayed with $4 \mathrm{ml}$ of $0.1 \%$ aqueous carboxymethyl cellulose, or with $50 \mathrm{~mm}$ of either glucose, fructose, or sucrose to analyze substrate induction and catabolite repression.

\section{Preparation of crude extracts and extracellular enzymes}

Crude homogenates of rust infection structures were made in

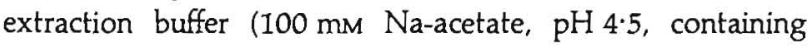

$1 \mathrm{~mm}$ PMSF, $1 \%(\mathrm{v} / \mathrm{v})$ methanol, $0.1 \%(\mathrm{v} / \mathrm{v})$ Triton $\mathrm{X}-100$, and $200 \mathrm{mM} \mathrm{NaCl}$ ). Five to ten membranes were used to measure total cellulase activity, and ten to 45 membranes were used to prepare extracts for column chromatography. Spores were homogenized by mortar and pestle; for germ tubes and infection structures a Potter-Elvehjem homogenizer (Kummer, Freiburg, Germany) was used. The homogenate was clarified by centrifugation $(20000 \mathrm{~g}, 20 \mathrm{~min})$, and to the supernatant crystalline $\left(\mathrm{NH}_{4}\right)_{2} \mathrm{SO}_{4}$ was added to $80 \%$ saturation. After centrifugation as described above, the protein precipitate was redissolved in $10 \mathrm{~mm}\left(\mathrm{NH}_{4}\right)$-acetate, $\mathrm{pH} 4.9,(0.1 \mathrm{ml}$ per membrane), and dialyzed (Visking dialysis tubing, $6.35 \mathrm{~mm}$, exclusion size $12-14 \mathrm{kDa}$ ) for $16 \mathrm{~h}$ against $5 \mathrm{l}$ of the same buffer. Remaining or newly formed precipitate was removed by centrifugation $(12000 \mathrm{~g}, 20 \mathrm{~min}$ ) to yield the crude extract.

To obtain extracellular fungal proteins, polyethylene membranes with adhering fungal structures were inverted and floated on extraction buffer for $15 \mathrm{~min}$ with slow agitation $(20 \mathrm{rpm})$. Thirty membranes were used to isolate extracellular material sufficient for column chromatography and subsequent measurement of enzyme activity. The washing fluid $(350 \mathrm{ml})$ was concentrated to $3 \mathrm{ml}$ by ultra-filtration (Amicon 8200 ultrafiltration cell and YM 5 filter, exclusion size $5 \mathrm{kDa}$ ) at 1.3 bar pressure. The concentrated material was dialyzed against $500 \mathrm{ml} 10 \mathrm{~mm}\left(\mathrm{NH}_{4}\right)$-acetate (pH 4.9) as described above.

\section{Sephadex G75-SF gel permeation chromatography}

Samples ( $1.0 \mathrm{ml}$ ) were applied to a Sephadex G75-SF column (378 $\mathrm{ml}$ gel bed, $84 \mathrm{~cm}$ long), equilibrated with $0.02 \%(\mathrm{w} / \mathrm{v})$ $\mathrm{NaN}_{3}$ in $0.2 \mathrm{M}\left(\mathrm{NH}_{4}\right)$-acetate buffer, $\mathrm{pH} 4.9$. The flow rate was $8.6 \mathrm{ml} \mathrm{h}^{-1}$. Fractions of $2.2 \mathrm{ml}$ were collected. Blue dextran $(2000 \mathrm{kDa}), \mathrm{BSA}(67 \mathrm{kDa})$, ovalbumin $(45 \mathrm{kDa})$, chymotrypsinogen $A(25 \mathrm{kDa})$, and cytochrome c $(12.3 \mathrm{kDa})$ (all from Sigma) were used to calibrate the column.

\section{Chromatofocusing}

In the acidic range ( $\mathrm{pH} 6.0$ to 2.8 ), chromatofocusing of crude extracts and extracellular proteins was carried out on a DEAE $=$ Si500 (0.02-0.04 mm, Serva, Heidelberg, Germany) column (13.1 ml gel bed, $16.8 \mathrm{~cm}$ long). The sample was dialyzed against $25 \mathrm{~mm}$ histidine- $\mathrm{HCl}, \mathrm{pH} 6.0$ for $16 \mathrm{~h}$. A volume of up to $3.0 \mathrm{ml}$, containing maximally $12.4 \mathrm{mg}$ protein $\mathrm{ml}^{-1}$, was applied to the column equilibrated with the same buffer. After adding $5 \mathrm{ml}$ histidine- $\mathrm{HCl}$ buffer, $\mathrm{pH} 6.0$, the $\mathrm{pH}$ gradient used to elute the proteins was generated by applying $0.5 \%$ (v/v) Servalyt 3-8 (Serva), adjusted to $\mathrm{pH} 3.9$, and $0.5 \%(\mathrm{v} / \mathrm{v})$ Servalyt 2-4 (Serva), pH 2.8.

Fractions containing proteins which did not bind to the $\mathrm{DEAE}=\mathrm{Si} 500$ column were pooled and concentrated to $3.0 \mathrm{ml}$ by ultrafiltration as described above. After adding

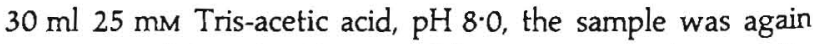
concentrated by ultrafiltration. The concentrate (maximally $3.0 \mathrm{ml}$ ) was applied to a PBE 94 (Pharmacia, Freiburg, Germany) column ( $8.9 \mathrm{ml}$ gel bed, $17.8 \mathrm{~cm}$ long), equilibrated with $25 \mathrm{~mm}$ Tris-acetic acid, $\mathrm{pH} 8 \cdot 0$. To elute proteins of the neutral $\mathrm{pI}$ range, a $\mathrm{pH}$ gradient was generated using Polybuffer 
PB 96, (Pharmacia, Freiburg, Germany), diluted $1: 13(\mathrm{v} / \mathrm{v})$ in distilled $\mathrm{H}_{2} \mathrm{O}$, adjusted to $\mathrm{pH} 6.0$ with acetic acid.

The flow rates were $13.5 \mathrm{ml} \mathrm{h}^{-1}(\mathrm{DEAE}=\mathrm{Si500})$ and $25.0 \mathrm{ml} \mathrm{h}^{-1}$ (PBE 94), the fraction sizes 1.6 and $2.1 \mathrm{ml}$, respectively.

All operations were carried out at $4^{\circ}$.

\section{Enzyme assays}

Cellulase. Photometric assay: To determine cellulase (endo- $\beta$ 1,4-glucanase [EC 3.2.1.4], exo- $\beta$-1,4-glucanase [EC $3 \cdot 2.1 .91$ ], and exo- $\beta-1,4-$ glucosidase [EC 3 . 2 . 1 . 74]) activity in crude extracts and in column chromatography fractions, the assay contained $1 \%(\mathrm{w} / \mathrm{v})$ carboxymethyl cellulose, Na-salt (CMC) (Serva, Heidelberg, Germany), and $0.02 \% \mathrm{NaN}_{3}(\mathrm{w} / \mathrm{v})$ in $50 \mathrm{~mm} \mathrm{Na}$-acetate, $\mathrm{pH} \mathrm{4.9}$. In a total volume of $500 \mu \mathrm{l}$, $50 \mu \mathrm{l}$ of the crude extract or $200 \mu \mathrm{l}$ of the column fractions were tested. The assays were run for $2 \mathrm{~h}$ (crude extract) or $24 \mathrm{~h}$ (column fractions) at $30^{\circ}$. To analyse the substrate specificity of the hydrolases, microcrystalline cellulose (Avicel PH 101, particle size $38 \mu \mathrm{m}$ ) and native cellulose (Cellulose MN 300, fiber chain length 2-20 $\mu \mathrm{m}$, both from Serva), $1 \cdot 0 \%$ $(w / v)$ each, were used instead of $C M C$ as the substrate. These latter substrates were kept in suspension by shaking throughout the enzyme reaction. The formation of reducing sugars was determined photometrically at $\lambda_{500 \mathrm{~nm}}$ according to Nelson (1944) and Somogyi (1952), or at $\lambda_{410 \mathrm{~nm}}$ using $p$ hydroxy benzoic acid hydrazide as described by Lever (1972).

Viscosimetric assay: Two $\mathrm{ml}$ of the pooled peak-fractions of chromatofocused cellulases were added to $2 \mathrm{ml} 1 \cdot 2 \%(\mathrm{w} / \mathrm{v})$ $\mathrm{CMC}$ and $0.04 \% \mathrm{NaN}_{3}$ in $100 \mathrm{~mm} \mathrm{Na}$-acetate buffer, $\mathrm{pH} 4.9$, and time-dependent changes in velocity were taken as a measure of enzyme activity (Canevascini \& Gattlen, 1981). At each viscosity determination time point, an aliquot of the reaction mixture was taken to determine the concentration of reducing sugars according to Lever (1972). Maximal available bonds were determined by reacting crude extract with the viscosity assay medium until no further alteration of the concentration of reducing sugars was detectable. The percentage of cleaved bonds was expressed on the basis of maximal available bonds.

P-D-glucosidase (EC 3.2.1.21). To $400 \mu$ of the chromatofocusing fractions, $100 \mu \mathrm{l}$ of a solution, containing $2.5 \mathrm{mg}$ p-nitrophenyl- $\beta$-D-glucopyranoside per $\mathrm{ml} 0.4 \mathrm{M} \mathrm{Na}$-acetate buffer ( $\mathrm{pH} 5.0$ ) was added. After incubation at $30^{\circ}$ for 12-15 h, $1 \mathrm{ml} 2 \mathrm{~mm} \mathrm{Na}{ }_{2}$-EDTA in $1 \mathrm{M}$ ammonia was added. After centrifugation ( $15000 \mathrm{~g}, 10 \mathrm{~min}$ at room temperature) the absorbance of the sample at $\lambda 405 \mathrm{~nm}$ was determined. Malate dehydrogenase (EC 1.1.1.37). Malate dehydrogenase activity was determined according to Sigma Technical Bulletin (No. 340-UV). The reaction mixture consisted of $136 \mu \mathrm{M}$ NADH and $150 \mu \mathrm{M}$ cis-oxaloacetate in $0.1 \mathrm{M} \mathrm{K}$ -

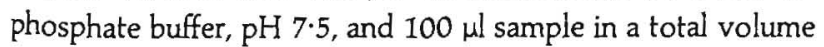
of $3.0 \mathrm{ml}$. The assay was run at $25^{\circ}$, and the decrease in $A_{\lambda 340 \mathrm{~nm}}$ was used as measure of enzyme activity.

\section{Protein determination}

Protein determination was done according to Bradford (1976), using a commercially available dye reagent (BioRad, München, Germany), and $\gamma$-globulin as the standard.

\section{RESULTS}

\section{Differentiation-specific formation of cellulose-degrading enzymes in $U$. viciae-fabae}

The kinetics of formation of total cellulolytic enzyme activities by $U$. oiciae-fabae, measured with $C M C$, native and micro-

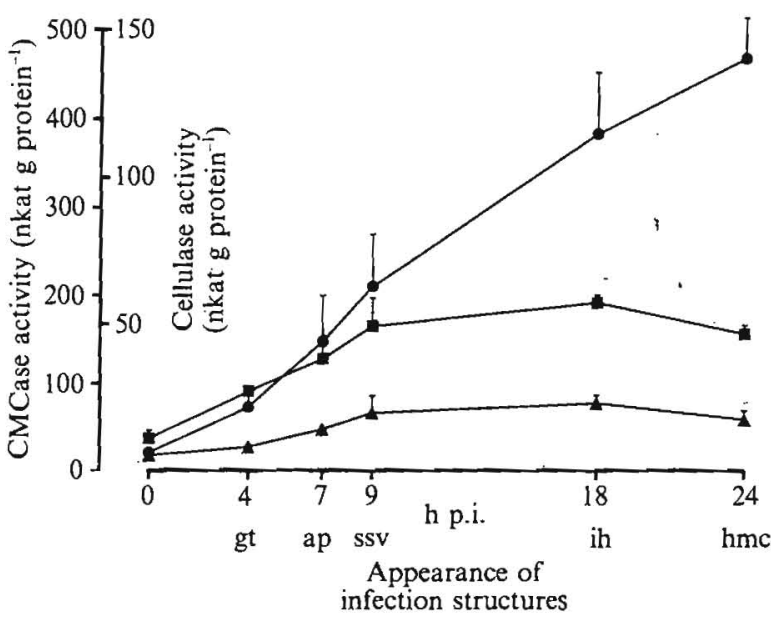

Fig. 1. Time-course of formation of cellulase activity in differentiating uredosporelings of Uromyces viciae-fabae. Uredospores were dusted onto thigmo-inducing polyethylene membranes and allowed to form infection structures. At different time points, corresponding to different structures formed, cellulase activity was measured using CMC (O), microcrystalline ( $\mathbf{A})$, or native cellulose ( $\mathbf{\square}$ ) as substrate. gt = germ tube, ap = appressorium, ssv = substomatal vesicle, ih $=$ infection hypha, hmc $=$ haustorial mother cell. Vertical bars represent S.D.

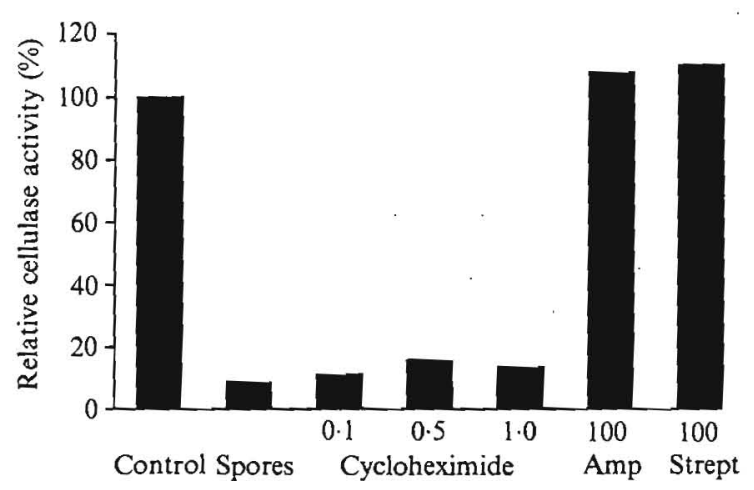

Fig. 2. Effect of cycloheximide, ampicillin and streptomycin sulphate on the formation of cellulase activity of Uromyces viciae-fabae. Cycloheximide was applied at concentrations of $0.1,0.5$ and $1.0 \mathrm{\mu g} \mathrm{ml} l^{-1}$. The concentrations of ampicillin (amp) and streptomycin sulphate (strept) were $100 \mu \mathrm{g} \mathrm{ml}^{-1}$. Untreated control spores (control) were sprayed with distilled $\mathrm{H}_{2} \mathrm{O}$. Enzyme activities of inhibitortreated and control spores were measured after $24 \mathrm{~h}$. For comparison, cellulase activity present in dormant spores (spores) was also determined. 
$(a)$

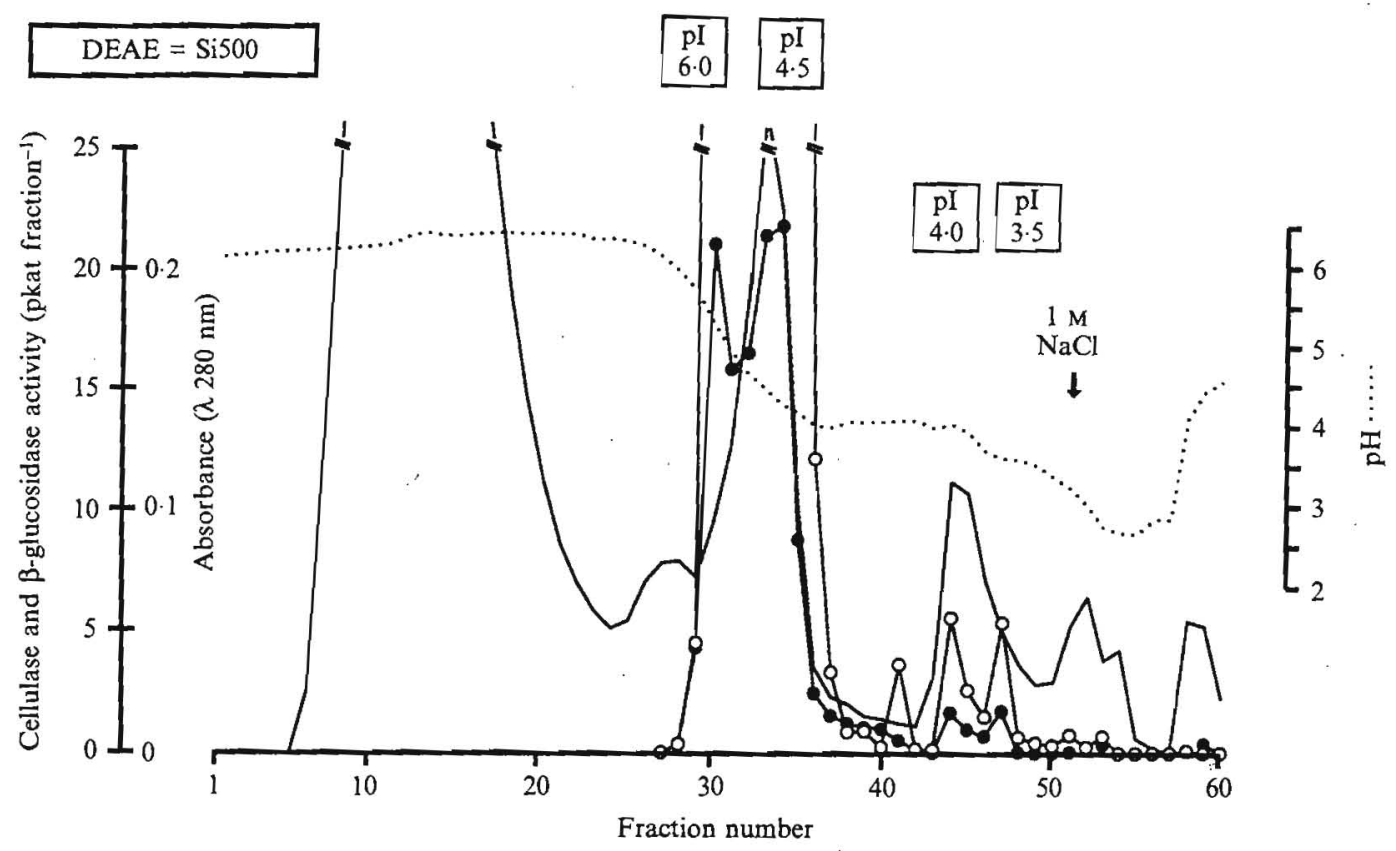

(b)

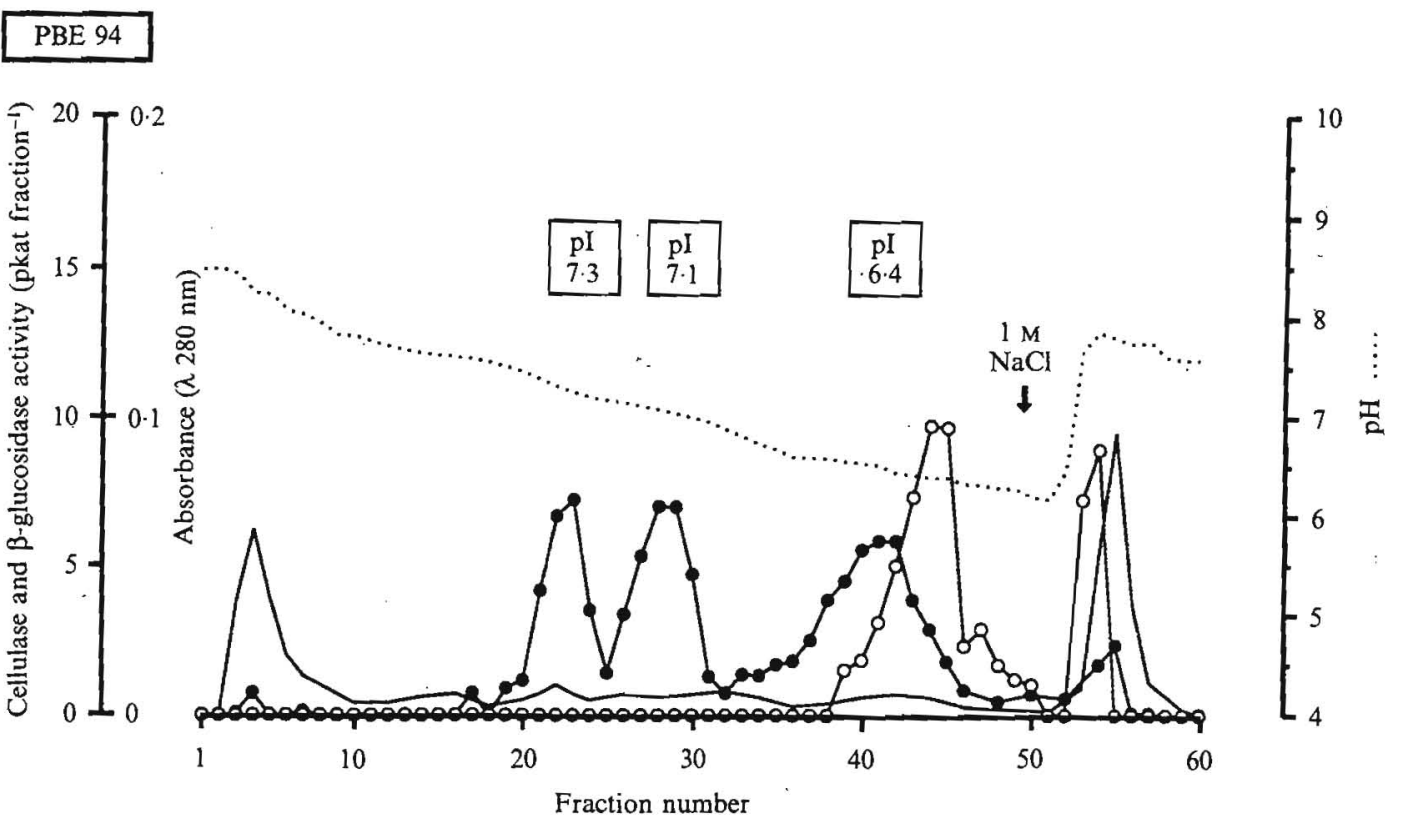

Fig. 3. Chromatofocusing of cellulolytic enzymes of Uromyces viciae-fabae on DEAE $=\mathrm{Si500}(a)$ and PBE 94 (b) exchangers. Crude extract from infection structures, differentiated for $24 \mathrm{~h}$, was applied to the DEAE $=\mathrm{Si} 500$ column. Non-bound proteins were dialysed against Tris-acetate, $\mathrm{pH} \mathrm{8.0,} \mathrm{concentrated,} \mathrm{and} \mathrm{applied} \mathrm{to} \mathrm{the} \mathrm{PBE} 94$ column. Proteins were eluted from both columns by applying pH gradients, and the fractions were analysed for cellulase $(-)$ and $\beta$-glucosidase $(O)$ activity. The dotted line indicates the $\mathrm{pH}$ gradient, the solid line gives the absorbance at $\lambda 280 \mathrm{~nm}$.

crystalline cellulose, is shown in Fig. 1. While low enzyme activities were found in both uredospores and germlings growing for $4 \mathrm{~h}$, activities started to increase during appressorium formation and reached a maximum at $18 \mathrm{~h}$ p.i., i.e. when infection hyphae developed. Similar activities were found when haustorial mother cells were produced ( $24 \mathrm{~h}$ p.i.). While the hydrolytic activity was more than ten-fold higher with CMC than with insoluble cellulose, the kinetics of enzyme formation were comparable with all substrates tested.
However, with CMC activity was still increasing at $24 \mathrm{~h}$ p.i., while with the insoluble substrates some decrease was observed.

When uredospores germinated on glass surfaces which provide no thigmotropic signal, only $2-5 \%$ of the specimens differentiated appressoria and subsequent infection structures. As compared to uredosporelings differentiating on thigmoinducing polyethylene membranes where cellulase activity increased by more than $400 \%$ (measured with CMC as the 


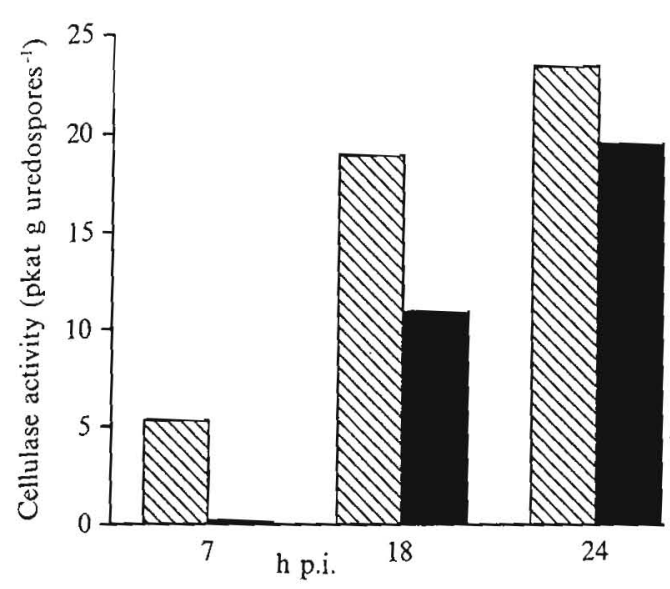

Fig. 4. Comparison of activities of acidic (hatched bars) and neutral cellulolytic enzymes (solid bars) at different stages of infection structure differentiation by Uromyces viciae-fabae. Crude extracts were prepared 7, 18, and $24 \mathrm{~h}$ after inoculation (h p.i.). Chromatofocusing was performed as shown in Fig. 2. Cellulolytic enzymes binding to the DEAE $=$ Si500 (acidic) and PBE 94 (neutral) column were measured as the rate of $\mathrm{CMC}$ hydrolysis.

Table 1. Substrate specificity of different cellulolytic enzymes of Uromyces viciae-fabae. Infection structures were allowed to differentiate for $24 \mathrm{~h}$. Crude protein extracts were chromatofocused on DEAE $=\mathrm{Si} 500$ and PBE 94 exchangers, and the separated enzymes active with CMC (pI 4.5, 6.4, $7 \cdot 1$ and $7 \cdot 3$ ) were tested with native (Cellulose MN 300) and microcrystalline cellulose (Avicel PH 101)

\begin{tabular}{|c|c|c|c|}
\hline \multirow[b]{2}{*}{ Enzymes } & \multicolumn{3}{|c|}{ Cellulase $e^{a}$ substrates } \\
\hline & $\mathrm{CMC}$ & $\begin{array}{l}\text { Native } \\
\text { cellulose }\end{array}$ & $\begin{array}{l}\text { Microcrystaalline } \\
\text { cellulòse }\end{array}$ \\
\hline $\begin{array}{l}\text { Crude extract } \\
\pm \text { s.D. }\end{array}$ & $\begin{array}{l}494.51(100) \\
\pm 0.02\end{array}$ & $\begin{array}{l}102.37(20.70) \\
\pm 0.05\end{array}$ & $\begin{array}{l}56.67(\mathrm{II} .47) \\
\pm 0.01\end{array}$ \\
\hline $\begin{array}{l}\text { PI } 4 \cdot 5 \\
\quad \pm \text { s.D. }\end{array}$ & $\begin{array}{l}39 \cdot 22(100) \\
\pm 4 \cdot 69\end{array}$ & $\begin{aligned} & 7.60(19 \cdot 40) \\
\pm & 0.63\end{aligned}$ & $\begin{aligned} & 5.59(14.23) \\
\pm & 0.08\end{aligned}$ \\
\hline $\begin{array}{l}\text { pI } 6.4 \\
\quad \pm \text { s.D. }\end{array}$ & $\begin{aligned} & 6.66(100) \\
\pm & 0.11\end{aligned}$ & $\begin{aligned} & 0.01(0.16) \\
\pm & 0.01\end{aligned}$ & $\begin{aligned} & 0.59(8.92) \\
\pm & 0.04\end{aligned}$ \\
\hline $\begin{array}{l}\text { Mixture of pI } \\
7 \cdot 1 \text { and pI } 7 \cdot 3 \\
\text { 土s.D. }\end{array}$ & $\begin{array}{l}16 \cdot 80(100) \\
\pm 1 \cdot 72\end{array}$ & $\begin{aligned} & 0.09(0.52) \\
\pm & 0.01\end{aligned}$ & 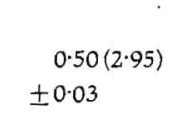 \\
\hline
\end{tabular}
activity.

${ }^{a}$ Cellulase activity in pkat $\mathrm{ml}^{-1}$; the figures in brackets represent relative

substrate), the enzyme activity in the controls (glass plates) increased only by $31 \%$ during $24 \mathrm{~h}$.

When aqueous solutions containing $0.1,0.5$, or $1.0 \mu \mathrm{g}$ cycloheximide $\mathrm{ml}^{-1}$ were sprayed onto rust uredospores, cellulase activity measured after $24 \mathrm{~h}$ did not differ significantly from the activity found in dormant spores (Fig. 2). While $0.1 \mu \mathrm{g}$ cycloheximide $\mathrm{ml}^{-1}$ did not inhibit germination, only few appressoria, substomatal vesicles and infection hyphae were observed; most of these structures were abnormally shaped. At $0.5 \mu \mathrm{g} \mathrm{ml}^{-1}$, cycloheximide caused reduced rates of germination, and appressoria were very rarely differentiated. At $1.0 \mu \mathrm{g} \mathrm{ml}^{-1}$ only some spores were able to germinate.
Compared with the untreated control, which was allowed to differentiate infection structures for $24 \mathrm{~h}$, ampicillin and streptomycin sulphate did not inhibit the formation of cellulase activity (Fig. 2) or the differentiation of infection structures.

Extracts of the broad bean rust infection structures were subjected to chromatofocusing on DEAE $=$ Si500 $(\mathrm{pH} \mathrm{6.0-}$ 2.8) and $\mathrm{PBE} 94$ ( $\mathrm{pH} \mathrm{8.0-6.0)} \mathrm{resins} \mathrm{and} \mathrm{seven} \mathrm{enzymes}$ exhibiting activity towards CMC were separated (Fig. 3). In the acidic range ( $\mathrm{pH} 6 \cdot 0-2 \cdot 8$ ), four enzymes with pls of 6.0 , $4 \cdot 5,4 \cdot 0$, and 3.5 were identified (Fig. $3 a$ ). In the neutral range (pH 8.0-6.0), three cellulolytic enzymes with pIs of $7 \cdot 3,7 \cdot 1$, and 6.4 were found (Fig. 3 b). In the basic range ( $\mathrm{pH} 10 \cdot 5-8.5$ ) no cellulase activity bound to or eluted from the PBE 118 exchanger. The elution profile of the cellulolytic enzymes with pIs of 6.0 to $3.5(\mathrm{DEAE}=\mathrm{Si500})$ precisely matched that of non-specific $\beta$-glucosidase activity, as measured with $p$ nitrophenyl- $\beta$-glucopyranoside as the substrate. In contrast, the $\mathrm{pI} 7 \cdot 3$ and 7.I CMCase fractions of the PBE 94 column did not show $\beta$-glucosidase activity, whereas the peak of the enzyme with pI 6.4 only partially overlaps with a more acidic $\beta$-glucosidase peak.

Chromatofocusing was also used to visualize the developmental production of the different cellulolytic enzymes (Fig. 4). When appressoria were formed ( $7 \mathrm{~h}$ p.i.), the large majority (97\%) of the cellulolytic activity bound to the $\mathrm{DEAE}=\mathrm{Si} 500$ column; only $3 \%$ of the total activity was eluted from the PBE 94 exchanger in the neutral $\mathrm{pH}$ range. When the fungus had differentiated infection hyphae (18 h p.i.), the neutral cellulases had increased to $37 \%$ of the total cellulolytic activity. After $24 \mathrm{~h}$, when approximately $15 \%$ of the fungal specimens had formed haustorial mother cells, the neutral enzymes represented $45 \%$ of the total activity.

\section{Molecular weight and $p H$ optima}

Sephadex G-75 SF chromatography was used to determine the molecular weight of the cellulases of the broad bean rust fungus. While $17 \%$ of the enzyme activity was found in the void volume of the column, $83 \%$ eluted as a broad peak with a maximum at approximately $42 \mathrm{kDa}$ and a shoulder at $48 \mathrm{kDa}$ (data not shown).

The $\mathrm{pH}$ optimum of all enzyme forms separated by chromatofocusing was $4 \cdot 9-5 \cdot 0$ with CMC as the substrate.

\section{Substrate specificity of crude extract and separated cellulases, and synergism of enzymes of the cellulase complex}

Crude extracts of $24 \mathrm{~h}$ old $U$. viciae-fabae infection structures, containing all cellulases and enzymes separated by chromatofocusing were tested for their activity on CMC and native and microcrystalline cellulose. The crude extract and all separated enzymes showed highest activity with CMC, whereas native cellulose was hydrolysed with $20.7 \%$ and microcrystalline cellulose with $11.5 \%$ of the rate found with CMC (Table 1). A similar result was obtained with the acidic cellulase (pI, 4.5). 
Table 2. Synergistic activities of cellulases of Uromyces viciae-fabae infection structures, differentiated for $24 \mathrm{~h}$. Cellulolytic enzymes separated by chromatofocusing on DEAE $=\mathrm{Si} 500$ and PBE 94 were tested alone and in mixtures of equal volumes for their ability to hydrolyze native (Cellulose MN 300) and microcrystalline cellulose (Avicel PH 101)

\begin{tabular}{lcc} 
Enzyme & \multicolumn{1}{c}{$\begin{array}{l}\text { Native } \\
\text { cellulose }\end{array}$} & $\begin{array}{l}\text { Microcrystalline } \\
\text { cellulose }\end{array}$ \\
\hline pI $4 \cdot 5$ & $2532 \cdot 3 \pm 211 \cdot 6$ & $1862 \cdot 9 \pm 26 \cdot 2$ \\
pl $6 \cdot 4$ & $3 \cdot 5 \pm 1 \cdot 0$ & $198 \cdot 1 \pm 12 \cdot 7$ \\
pl $7 \cdot 1+7 \cdot 3$ & $28 \cdot 8 \pm 0 \cdot 5$ & $165 \cdot 3 \pm 8 \cdot 5$ \\
$\Sigma$ & $2564 \cdot 6 \pm 213 \cdot 2$ & $2226 \cdot 3 \pm 4 \cdot 0$ \\
pI $4 \cdot 5+6 \cdot 4+$ & $4999 \cdot 0 \pm 217 \cdot 0$ & $3545 \cdot 5 \pm 332 \cdot 84$ \\
$7 \cdot 1+7 \cdot 3$ & & \\
& \\
\hline
\end{tabular}

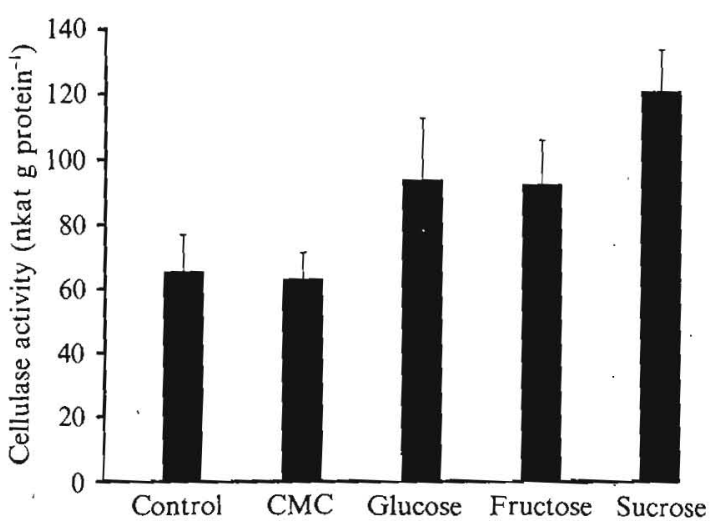

Fig. 5. Effect of CMC, glucose, fructose, and sucrose on the cellulase activity of Uromyces viciae-fabae. Sterile distilled water (control), solutions containing $50 \mathrm{~mm}$ glucose, fructose or sucrose, or $0.1 \%$ $(w / v)$ CMC were sprayed onto thigmo-inducing membranes inoculated with uredospores. After $24 \mathrm{~h}$, infection structures were homogenized and cellulase activity was determined using CMC as the substrate. Vertical bars represent S.D.

In contrast, the enzymes characterized by $\mathrm{pI} 7 \cdot 3,7 \cdot 1$ and $6 \cdot 4$, once separated by chromatofocusing, hydrolyzed the nonsoluble celluloses at very low rates.

To test synergistic effects, the separated cellulolytic enzymes were incubated with native and microcrystalline cellulose, and the activity was compared with that of the mixture of all separated enzymes (Table 2). The only enzyme showing substantial degradation of native cellulose was the acidic enzyme (pI 4.5). The neutral cellulases exhibited only traces of activity with microcrystalline and very low activities with native cellulose. Importantly, the arithmetric sum of the individual activities was only $51.3 \%$ (native cellulose) and $62.8 \%$ (microcrystalline cellulose) of the activity of all cellulases present in one reaction.

\section{Substrate induction and catabolite repression of cellulase activity}

Substrate-inducibility of cellulases and a possible repression of these enzymes by sugars was tested by spraying uredospores with either $0.1 \% \mathrm{CMC}$, the monosaccharides glucose and
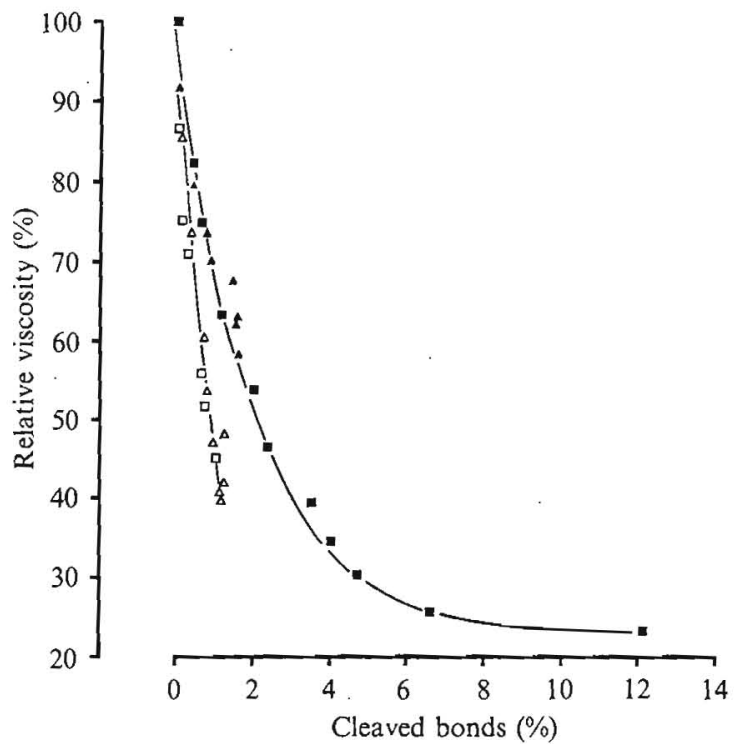

Fig. 6. Decrease in substrate viscosity as a function of bonds cleaved by different cellulolytic enzymes of Uromyces viciae-fabae. Enzymes with different isoelectric points $(\triangle$, pI $7 \cdot 3 ; \square$, pI $7 \cdot 1 ; \boldsymbol{\Lambda}$, pI $6 \cdot 4 ;$ pI 4.5), as separated by chromatofocusing were used in this assay. CMC served as the substrate. Reducing ends formed were measured according to Lever (1972). Maximal available bonds were determined using crude enzyme extracts containing all cellulolytic enzymes of the rust fungus.

fructose, or the disaccharide sucrose ( $50 \mathrm{~mm}$ each) immediately after inoculation of the polyethylene sheets. Addition of CMC caused no effect on the enzyme activity, but glucose, fructose and sucrose resulted in increases in cellulase activity of $43.3 \%$, $41 \cdot 2 \%$, and $84.6 \%$, respectively (Fig. 5 ).

\section{Characterization of the mode of substrate cleavage}

Four cellulolytic enzymes, separated by chromatofocusing, were compared for their ability to reduce the viscosity of their substrate CMC as a function of cleaved $\beta$-1,4-bonds (Fig. 6). Whereas the cellulases with pI $7 \cdot 3$ and $7 \cdot 1$ caused $50 \%$ viscosity reduction at $0.85 \%$ cleaved bonds, the enzymes with pI 6.4 (which showed some $\beta$-glucosidase contamination), and pI 4.5 (which co-eluted with $\beta$-glucosidase) caused $50 \%$ reduction of substrate viscosity at more than $2.2 \%$ of the maximal available bonds cleaved.

\section{Extracellular cellulase activity}

The extracellular fraction of cellulolytic activity was determined after floating the inverted membranes with adhering infection structures ( $24 \mathrm{~h}$ p.i.) on extraction buffer. For comparison, the extracellular portion of proteins and of the activity of the cytoplasmic marker enzyme malate dehydrogenase were determined as well. In contrast to protein and malate dehydrogenase activity, significant amounts of cellulase activity was found extracellularly. The large majority of extracellular cellulase activity (91.5\%) was found in the acidic (pI 4.5) fraction (Table 3). 
Table 3. Extracellular fraction of cellulase activity, protein, and cytoplasmic malate dehydrogenase activity in Uromyces viciae-fabae infection structures, differentiated for $24 \mathrm{~h}$

Extracellular

fraction \pm S.D.
Total cellulase activity

Activity of acidic cellulases ${ }^{a}$

Activity of neutral cellulases Protein

Malate dehydrogenase activity

$50 \cdot 6 \pm 10 \cdot 82$

$46 \cdot 3 \pm 3 \cdot 54$

$4 \cdot 3 \pm 3 \cdot 54$

$7 \cdot 6 \pm 4 \cdot 30$

$2 \cdot 0 \pm 1 \cdot 39$
${ }^{a}$ Cellulase activity, "amount of protein, and "malate dehydrogenase activity are given as $\%$ of the total (intracellular plus extracellular) activity or amount.

\section{DISCUSSION}

The kinetics of formation of cellulolytic enzyme activity during infection structure differentiation of $U$. viciae-fabae has been studied in the absence of its host plant, using polyethylene membranes providing a thigmotropic signal.

Native and microcrystalline cellulose were hydrolysed at lower rates than the water-soluble model substrate $\mathrm{CMC}$, but the kinetics of formation of cellulase and CMCase activity were similar. The enzymes of the cellulase complex of $U$. viciae-fabae, like those of other fungi (Fan, Gharpuray \& Lee, 1987, and literature therein), appear to act synergistically in the degradation of native cellulose. Some of these enzymes, once separated from the functional unit, although clearly contributing to the cellulase complex, do not significantly degrade native cellulose but hydrolyse CMC at high rates. Therefore, although occasionally suggested otherwise (Reese, Siu \& Levingson, 1950; Halliwell, 1961), CMC represents a useful substrate in biochemical studies designed to analyse kinetics of the formation and properties of the different cellulase components (Sharrock, 1988). The higher sensitivity of the assay with $\mathrm{CMC}$ as compared with non-soluble cellulose is of special importance since $U$. viciae-fabae, and probably the majority of obligate biotrophs, produces very low levels of cellulase activity.

Dormant uredospores contain some cellulase activity which increased during germination. Upon appressorium formation, the activity increased considerably and reached a maximum of approximately 20 times the activity found in spores when infection hyphae and haustorial mother cells were formed. The fact that the increase in cellulase activity was completely inhibited even by low concentrations of the $80 \mathrm{~S}$ ribosomespecific protein synthesis inhibitor cycloheximide (Obrig et al., 1971), but not by high concentrations of the $70 \mathrm{~S}$ ribosomespecific inhibitor streptomycin sulphate (Flaks, Cox \& White, 1962) or by the bacterial cell wall synthesis inhibitor ampicillin (Waxman \& Strominger, 1983) indicates that the enzyme activity was not due to bacterial contaminants of uredospores. Furthermore, this result suggests that the development-related increase might be due to de nooo synthesis of the enzymes. The latter assumption needs further experimental support, e.g. by probing blotted proteins of different developmental stages with monospecific antibodies directed against rust cellulase.

Cellulolytic activity consists of several different enzymes or (iso-) forms. Multiplicity of enzyme forms is well-documented in fungi; multiple cellulase forms, however, can result from both, pre- and post-secretional (proteolytic) events (NikuPaavola et al., 1985; Willnick \& Seligy, 1985 ; Messner, Gruber \& Kubicek, 1988; Hagspiel, Haab \& Kubicek, 1989). Analysis of $U$. viciae-fabae cellulases separated by chromatofocusing revealed that the neutral enzymes especially increased during late stages of infection structure differentiation, i.e. when infection hyphae and haustorial mother cells develop prior to penetration of the host cell wall.

Differentiation and enzyme formation by the broad bean rust fungus occur in the absence of potential inducers (cellulose) or repressors (low molecular weight sugars). The addition of CMC to infection structures did not enhance cellulase activity, but sugars such as glucose, fructose, or sucrose markedly increased the enzyme activity. This is in marked contrast to cellulases from other fungi. Cellulases have been shown to be substrate-inducible in necrotrophic fungi and in fungi non-pathogenic to plants. Sclerotinia sclerotiorum, Fusarium oxysporum, and Neurospora crassa produce cellulases in culture media containing cellulose (Lumsden, 1969; Olutiola, 1978; Yazdi et al., 1990; Riou, Freyssinet \& Fevre, 1991). Also, catabolite repression of cellulase formation in fungi has been reported frequently. For instance, Bagga, Sandhu \& Sharma (1989) demonstrated that the addition of glucose to a medium containing CMC significantly repressed all components of the cellulase complex of Aspergillus nidulans. Horton \& Keen (1966) showed that $500 \mu \mathrm{M}$ glucose was sufficient to repress the cellulase of the plant pathogen Pyrenochaeta terrestris. The 100-fold glucose concentration $(50 \mathrm{~mm})$, which is in the physiological range of sugars found in plant apoplasts (Holz \& Knox-Davies, 1986), did not repress cellulase activity of the rust fungus $U$. viciae-fabae. Kaminskyj \& Day (1984) observed that $50 \mathrm{~mm}$ fructose, glucose, sucrose and trehalose induce differentiation of infection structures in the bean rust fungus $U$. phaseoli var. typica and result in longer growth and viability. Therefore, rust fungi are able to take up and utilize nutrients from surrounding media before having differentiated haustoria. An increase of enzyme activity in the presence of sugars could thus be due to increased viability and/or rate of differentiation of infection structures. Since rust fungi need to penetrate the host cell wall and form haustoria in the host cell, catabolite repression of cell wall-degrading enzymes such as cellulases would counteract the strategy of biotrophy, and the lack of catabolite control found for cellulases in U. viciae-fabae thus appears reasonable.

Chong et al. (1981) and Taylor \& Mims (1991) have shown highly localized dissolution of the plant cell wall surrounding the infection peg of rust fungi. These and similar microscopical studies suggest the involvement of cell wall-degrading enzymes in the penetration process. In order to better understand the role played by cellulases in this biotrophic pathosystem, studies on their cleavage type and localization within the infected tissue are required. Since endo-cleaving enzymes are much more destructive than exo-acting cell walldegrading enzymes, the cleavage type of the rust cellulases was examined. Viscosimetrical measurements suggest that the cellulases with pI 7.3 and $7 \cdot 1$ are true endo-cellulases.

With uredosporelings of the broad bean rust fungus $U$. 
viciae-fabae, differentiated up to haustorial mother cells, approximately $50 \%$ of the total cellulase activity was found extracellularly. This extracellular activity is mainly composed of the acidic enzyme (pI 4.5), which is able to degrade native and microcrystalline cellulose in the absence of the other hydrolytic enzymes found in crude extracts. None of the cellulases formed at late stages of infection structure differentiation, however, were detected in extracellular material. Since these endo-cleaving enzymes could increase the efficiency of penetration, we speculate that they are either bound to the cell wall or that their secretion is blocked until the penetration peg is beginning to form. This and subsequent structures are missing in haustorial mother cells induced on artificial membranes. Only after contact with the host mesophyll cell (Mendgen, 1982) or after induction with certain sugars (Heath, 1990), are such structures produced. However, in haustorial mother cells produced on membranes, a rim which strengthens the fungal wall around the penetration peg is observed (Freytag \& Mendgen, 1991). It would be interesting to immunocytochemically determine whether endocleaving cellulases are localized in this area. Interestingly, Wolf and co-workers (personal communication, G.A. Wolf, Göttingen, Germany) have detected cellulase activity in the apoplast of French bean (Phaseolus vulgaris) leaves infected with the bean rust fungus $U$. appendiculatus. Taken together, these results suggest that cellulases might be involved in a coordinated manner during penetration of host cell walls by rust fungi.

This work has shown for the first time that cellulases are produced by rust fungi. The expression of cellulase activity by $U$. viciae-fabae is controlled by mechanisms active during differentiation of infection structures. Substrate induction and catabolite repression are not involved in the regulation of cellulase activity. These findings are in contrast to results obtained from other fungi, and support the concept that polymer-degrading enzymes in obligate biotrophs and necrotrophs or saprophytic fungi are regulated by essentially different mechanisms (Deising \& Mendgen, 1992). Based on these data, investigations on the regulation of these enzymes at the transcriptional level are underway.

We thank Dr M. Hahn and Dr G. Sweet, Universität Konstanz, Germany, for critically reading the manuscript, and the Deutsche Forschungsgemeinschaft for grants to K.M. and H.D. (Me-523/14-1).

\section{REFERENCES}

Bagga, P. S., Sandhu, D. K. \& Sharma, S. (1989). Catabolite repression of cellulase production in Aspergillus nidulans. Process Biochemistry 24, 41-45.

Bradford, M. M. (1976). A rapid and sensitive method for the quantitation of microgram quantities of protein utilizing the principle of protein-dye binding. Analytical Biochemistry 72, 248-254.

Canevascini, G. \& Gattlen, C. (1981). A comparative investigation of various cellulase assay procedures. Biolechnology and Bioengineering 23, 1573-1590.

Chong, ]., Harder, D. E. \& Rohringer, R. (1981). Ontogeny of mono- and dikaryotic rust haustoria: Cytochemical and ultrastructural studies. Phytopathology 71, 975-983
Cooper, R. M. (1984). The role of cell wall-degrading enzymes in infection and damage. In Plant Diseases: Infection, Damage and Loss (ed. R. K. S. Wood \& G. J. Jellis), pp. 13-27. Blackwell Scientific Publications: Oxford.

Crawford, M. S. \& Kolattukudy, P. E. (1987). Pectate lyase from Fusarium solani f.sp. pisi: Purification, characterization, in vitro translation of the mRNA, and involvement in pathogenicity. Archioes of Biochemistry and Biophysics 258, 196-205.

Deising, H., Jungblut, P. R. \& Mendgen, K. (1991). Differentiation-related proteins of the broad bean rust fungus Uromyces viciae-fabae, as revealed by high resolution two-dimensional polyacrylamide gel electrophoresis. Archioes of Microbiology 155, 191-198.

Deising, H. \& Mendgen, K. (1992). Developmental control of enzyme production and cell wall modification in rust fungi, and defence reactions of the host plant. In: Molecular Biology of Filamentous Fungi (ed. U. Stahl \& P. Tudzynski) (pp. 27-44). VCH Publishers: Weinheim, Germany.

Dickinson, S. (1949). Studies in the physiology of obligate parasitism. II. The behaviour of the germ tubes of certain rusts in contact with various membranes. Annals of Botany 13, 219-236.

Dickman, M. B., Podila, G. K. \& Kolattukudy, P. E. (1989). Insertion of cutinase gene into a wound pathogen enables it to infect intact host. Nature $342,446-448$.

Fan, L. T., Gharpuray, M. M. \& Lee, Y. H. (1987). Enzymatic hydrolysis. In: Cellulose Hydrolysis (ed. L. T. Fan, M. M. Gharpuray \& Y.H. Lee), PP. 21-52. Springer Verlag: Berlin, Heidelberg

Flaks, J. G., Cox, E. C. \& White, J. R. (1962). Inţibition of polypeptide synthesis by streptomycin. Biochemical and Biophysical Research Communication 7, 385-389.

Freytag, S. \& Mendgen, K. (1991). Surface carbohydrates and cell wall structure of in vitro-induced uredospore infection structures of Uromyces viciae-fabae before and after treatment with enzymes and alkali. Protoplasma 161, 94-103.

Hagspiel, K., Haab, D.' \& Kubicek, C. P. (1989). Protease activity and proteolytic modification of cellulases from a Trichoderma reesei QM9414 selectant. Applied Microbiology and Biotechnology 32, 61-67.

Halliwell, G. (1961). The action of cellulolytic enzymes from Myrothecium verrucaria. Biochemical Joumal 79, 185-192.

Heath, M. C. (1990). Influence of carbohydrates on the induction of haustoria of the cowpea rust fungus in vitro. Experimental Mycology 14, 84-88.

Hoch, H. C., Staples, R. C., Whitehead, B., Comeau, J. \& Wolf, E. D. (1987). Signaling for growth orientation and cell differentiation by surface topography in Uromyces. Science 235, 1659-1662.

Holz, G. \& Knox-Davies, P. S. (1986). Possible involvement of apoplast sugar in endo-pectin-trans-eliminase synthesis and onion bulb rot caused by Fusarium oxysporum f.sp. cepae. Physiological and Molecular Plant Pathology 28, 403-410.

Horton, J. C. \& Keen, N. T. (1966). Regulation of induced cellulase synthesis in Pyrenochaeta terrestris Gorenz et al. by utilizable carbon compounds. Canadian Journal of Microbiology 12, 209-220.

Kaminskyj, S. G. \& Day, A. W. (1984). Chemical induction of infection structures in rust fungi. I. Sugars and complex media. Experimental Mycology 8, 63-72.

Keon, J. P. R., Byrde, R. J. W. \& Cooper, R. M. (1987). Some aspects of fungal enzymes that degrade plant cell walls. In: Fungal infection of Plants (ed. G. F. Pegg \& P.G. Ayres). pp. 133-157. Cambridge University Press: Cambridge, New York, New Rochelle.

Köller, W., Allan, C. R. \& Kolattukudy, P. E. (1982). Role of cutinase and cell wall degrading enzymes in infection of Pisum satioum by Fusarium solani f.sp. pisi. Physiological Plant Pathology 20, 47-60.

Lever, M. (1972). A new reaction for colorimetric determination of carbohydrates. Analytical Biochemistry 47, 273-279.

Lumsden, R. D. (1969). Sclerotinia sclerotionum infection of bean and the production of cellulase. Phytopathology 59, 653-657.

Mendgen, K. (1982). Differential recognition of the outer and inner walls of epidermal cells by a rust fungus. Naturwissenschaften 69, 502-503.

Mendgen, K., Schneider, A., Sterk, M. \& Fink, W. (1988). The differentiation of infection structures as a result of recognition events between some biotrophic parasites and their hosts. Joumal of Phytopathology 123, 259-272.

Messner, R., Gruber, F. \& Kubicek, C. P. (1988). Differential regulation of synthesis of multiple forms of specific endoglucanases by Trichoderma reesei QM9414. Journal of Bacteriology 170, 3689-3693. 
Nelson, N. (1944). A photometric adaptation of the Somogyi method for the determination of glucose. Journal of Biological Chemistry 153, 375-380.

Niku-Paavola, M.-L., Lappalainen, A., Enari, T.-M. \& Nummi, M. (1985). A new appraisal of the endoglucanase of the fungus Trichoderma reesei. Biochemical Joumal 231, 75-81.

Obrig, T. G., Culp, W. J., McKeehan, W. L. \& Hardesty, B. (1971). The mechanism by which cycloheximide and related glutarimide antibiotics inhibit peptide synthesis on reticulocyte ribosomes. The Journal of Biological Chemistry 246, 174-181.

Olutiola, P. O. (1978). Growth, sporulation and production of pectic and cellulolytic enzymes in Fusarium oxysporum. Transactions of the British Mycological Sociefy 70, 109-114.

Reese, E.T., Siu, R. G. H. \& Levingson, H. S. (1950). The biological degradation of soluble cellulose derivatives and its relationship to the mechanism of cellulose hydrolysis. Journal of Bacteriology 59, 485-497.

Riou, C., Freyssinet, G. \& Fevre, M. (1991). Production of cell wall-degrading enzymes by the phytopathogenic fungus Sclerotinia sclerotionum. Applied and Environmental Microbiology 57, 1478-1484.

Sharrock, K. R. (1988). Cellulase assay methods: A review. Journal of Biochemical and Biophysical Methods 17, 81-106.

Somogyi, M. (1952). Notes on sugar determination. Joumal of Biological Chemistry 195, 19-23.

Staples, R. C., Grambow, H. J., Hoch, H. C. \& Wynn, W. K. (1983). Contact with membrane grooves induces wheat stem rust uredospore germlings to differentiate appressoria but not vesicles. Phytopathology 73, 1436-1439.
Taylor, J. \& Mims, C. W. (1991). Fungal development and host cell response to the rust fungus Puccinia substriata var. indica in seedlings of susceptible and resistant pearl millet. Canadian Journal of Botany 69, 1207-1219.

Urbanek, H. (1989). The role of cutinase and cell wall degrading enzymes produced by Fusarium in pathogenesis. In Fusarium: Mycotoxins, Taxonomy and Pathogenicity, vol 2 (ed. J. Chelkowski), pp. 243-256. Elsevier Science Publishers: Amsterdam, Oxford, New York, Tokyo.

Van Sumere, C. F., Van Sumere-De Preter, C. \& Ledingham, G. A. (1957), Cell-wall-splitting enzymes of Puccinia graminis var. tritici. Canadian Joumal of Microbiology 3, 761-770.

Waxman, D. J. \& Strominger, J. L. (1983). Penicillin-binding proteins and the mechanism of action of $\beta$-lactam antibiotics. Annual Review of Biochemistry $52,825-869$

Willick, G. E. \& Seligy, V. L. (1985). Multiplicity in cellulases of Schizophyllum commune, derivation partly from heterogeneity in transcription and glycosylation. European Journal of Biochemistry 151, 89-96.

Wood, R. K. S. (1960). Pectic and cellulolytic enzymes in plant disease. Annual Reoiew of Plant Physiology 11, 299-322.

Wynn, W. K. (1976). Appressorium formation over stomates by the bean rust fungus: Response to a surface contact stimulus. Phytopathology 66, 136-146.

Yazdi, M. T., Woodward, J. R. \& Radford, A. (1990). Cellulase, production by Neurospora crassa: The enzymes of the complex and their regulation. Enzyme and Microbiological Tecknology 12, 116-119. 